\title{
Leszek Dziawgo
}

Nicolaus Copernicus University

e-mail: ldziawgo@econ.umk.pl

ORCID: 0000-0003-3666-7651

\section{ECOLOGICAL INVESTMENT FUNDS IN GERMAN-SPEAKING EUROPE}

\section{EKOLOGICZNE FUNDUSZE INWESTYCYJNE W NIEMCZECH, AUSTRII, SZWAJCARII I LUKSEMBURGU}

DOI: 10.15611/pn.2019.5.04

JEL Classification: D53, E22, G15, G23, Q01

\begin{abstract}
Summary: The aim of the article is to present and analyze fundamental data concerning the market of ecological investment funds (EIF) in German-speaking Europe (GSE) to assess the current state and prospects for this market. The hypothesis in the paper is formulated as follows: "The ecological investment funds market has been developing dynamically in the GSE region". In the research paper, critical aspects of the functioning of socially responsible investment (SRI), both theoretical and practical, were also presented as well. The following research methods were used: critical analysis of the literature, desk research, descriptive, comparative methods and deduction method. The results prove the above-mentioned hypothesis. The primary conclusion from the research is that further development of the described market is to be expected. It was also hinted that achievements in the ecological evolution of the financial markets could become the inspiration for the financial market in Poland.
\end{abstract}

Keywords: financial market, sustainable finance, responsible investment, ecological investment funds.

Streszczenie: Celem artykułu jest prezentacja i analiza podstawowych danych dotyczących rynku ekologicznych funduszy inwestycyjnych na obszarze Niemiec, Austrii, Szwajcarii i Luksemburga, aby określić stan i perspektywy tego rynku. Hipoteza postawiona w artykule brzmi, iż na analizowanym obszarze dynamicznie rozwija się rynek ekologicznych funduszy inwestycyjnych (EFI). W materiale zaprezentowano również aspekty krytyczne funkcjonowania inwestowania społecznie odpowiedzialnego (SRI) w aspekcie zarówno teoretycznym, jak i praktycznym. Przygotowując niniejsze opracowanie, wykorzystano następujące metody badawcze: krytycznej analizy literatury przedmiotu, danych zastanych, opisową, porównawczą, dedukcji. Uzyskane wyniki potwierdzają hipotezę. Podstawowym wnioskiem z przeprowadzonych badań jest to, że można oczekiwać dalszego rozwoju opisywanego rynku. Wskazano 
również, że osiągnięcia w zakresie ekologicznej ewolucji rynku finansowego mogą stanowić inspirację dla polskiego rynku finansowego.

Słowa kluczowe: rynek finansowy, zrównoważone finanse, odpowiedzialne inwestowanie, ekologiczne fundusze inwestycyjne.

\section{Introduction}

The idea of corporate social responsibility (CSR) has been pushing towards an ethical revolution in the economy, the including financial markets. One of the most essential components of CSR is protection of the natural environment. Changes in economic processes, both on a local and international scale, have been developing inrespect of ecological criteria. Financial market institutions have been using ecological aspects in their activity, with several leaders highlighted as well.

The aim of the article is to present and analyse fundamental data concerning the market of ecological investment funds (EIF) in German-speaking Europe (GSE) to assess the current state and prospects for this market. This area includes Germany, Austria, Switzerland and Luxembourg, and is one of the most vital regions in the current economy and the global financial market. It is known for excellent business culture, as well as its high activity on the part of business and society towards socioeconomic challenges. This also applies to corporate social responsibility (CSR), including protection of the natural environment.

The hypothesis in the paper is formulated as follows: "The ecological investment funds market has been developing dynamically in the GSE region." This may be evidenced by the increased number of ecological investment funds, as well as by the growth in their total value of financial assets. At present there are 225 such funds and the total value of their financial assets is estimated at over 54 billion EUR. Several other reasons behind the development of the EIF market can also be pointed out. The critical aspects of the functioning of socially responsible investment (SRI), both theoretical and practical, are presented as well.

In order to verify the hypothesis the following research methods were used: critical analysis of the literature, desk research, descriptive, comparative methods and deduction method. In the article only the results of the above-mentioned and applied methods are presented.

The results verified the hypothesis positively, and prove the above-mentioned hypothesis. The primary conclusion from the research is that further development of the described market is to be expected. It was also suggested that achievements in the ecological evolution of the financial market could become an inspiration for the Polish financial market. 


\section{Ecological revolution of the financial market}

The current financial market has been undergoing constant changes due to both endogenous and exogenous factors. One of the most significant is the idea of Corporate Social Responsibility (CSR), whose integral part is the coexistence between human and natural environment, as well as in economic processes. However, the idea of CSR has also been evolving (for instance the concepts of ESG, $\mathrm{CC}^{1}$ ). Caring for the natural environment has been attracting significantly more understanding and social support. Due to social and economic pressure, financial institutions are being pushed to consider the ecological aspects of business activity. Before this, protection of the natural environment was considered a costly extravagance, but nowadays it is rather a necessity and the opportunity to maintain and increase the value of the financial institution.

Financial institutions are able to support the protection of the natural environment though numerous ways (Dziawgo, 2014). The types of pro-ecological activities of financial market institutions are presented in Figure 1.

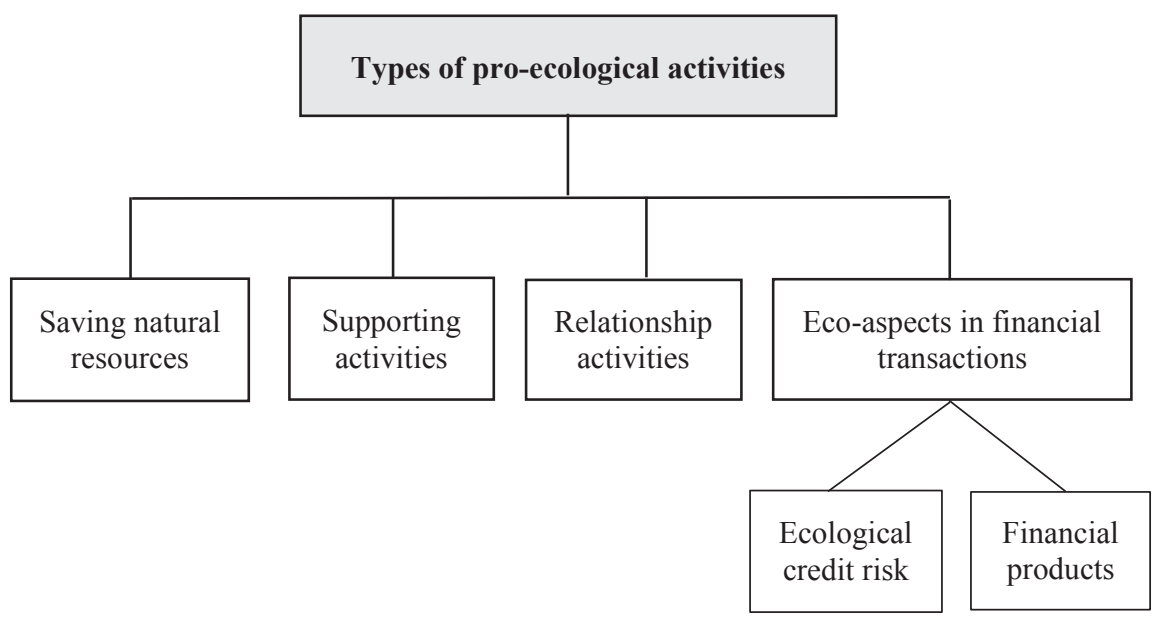

Fig. 1. Types of pro-ecological activities of financial market institutions

Source: own analysis.

In considering Figure 1, it is worth noting that saving the natural resources used in business activity is an important task in protecting the natural environment. This is regarded as a fundamental aspect of pro-ecological activity in every entity, including financial institutions. This concerns for instance, saving electric and heat energy, water, paper and fuel. This kind of activity can be described as 'own' eco-ecology.

\footnotetext{
${ }^{1}$ ESG - Environment, Social, Governance; CC - Corporate Citizenship.
} 
The other kind of activity concerning protection of the natural environment is supporting external institutions and pro-ecological actions, e.g. financially supporting selected NGOs.

Increasingly more important activities concerning the protection of natural environment are also the relations towards stakeholders of financial institutions and other entities (Dziawgo, 2012). This includes obligatory and voluntary information disclosure on ecological engagement from the institution.

All the above-mentioned types of pro-ecological activity in business are universal for every business entity. In financial institutions however, the application of ecological criteria in the financial product range is more significant. This concerns not only considering the ecological risk in credit risk assessment, but also offering products linked to protection of the natural environment, such as deposits, policies, bonds, shares and investment funds.

More and more financial institutions are undertaking such actions on protecting the natural environment on a larger scale. Among them are banks, insurance companies, brokerage houses, asset management companies, pension funds, private equity funds and investment fund associations. Such activity is becoming more systematic and complex. What is more, financial institutions specialized in financing protection of the natural environment are now present in the financial markets.

In the international financial markets, the engagement of financial institutions is varied in terms of the ecological quality of the undertaken actions and the amount of raised capital through offering specialized financial products linked to protection of the natural environment. The most advanced markets in this aspect are North America, Japan and Western Europe (Eurosif 2019).

\section{Ecological investment fund}

A notable part of the pro-ecological activity from financial institutions is offering participation units in ecological investment funds (EIF). Such funds run their investment policy with special regard for the stake of shares of companies which could be considered socially responsible and pro-ecological. Therefore the issuers run a business activity in respect of protection of the natural environment.

Due to the high scope of CSR, such funds are considered as ethical-ecological (Gabriel, 2007, pp. 102-103; Ulshoefer, and Bonnet, 2009, pp. 45-63; Upgang, 2009, pp. 120-124; Dziawgo, 2010; Staub-Bisang, 2012, pp. 11-12; Krupa, 2012; Deml, and Blisse, 2016). Naturally, the degree and quality of the pro-ecological activity of issuer are often subject to disputes from stakeholders, including investors, which further increase the importance of such disputes. To conclude however, an ecological investment fund is one that invests part or even the total capital in issuers that could be considered as pro-ecological by investors. Hence, the assessment of the ecological quality of the investment decision of the fund may be considered as subjective. 
It is worth noting however, that both the financial and ecological efficiency of the investment are significant in ecological investment funds. This is important due to the fact that it places such funds on financial markets accordingly, in compliance with the economy paradigm and financial market logic, in which the criterion of efficient business activity is profit. In this case, equal investment criterion is also the ecological efficiency of the issuer.

Nowadays, thousands of investment funds which could be considered as partially or fully ecological, operate on the international financial markets. They vary in terms of ecological criteria, type of such fund, object of investment and the market on which they are offered.

\section{EFI market development in German-speaking Europe}

The financial market in German-speaking Europe is one of the most vital parts of the present financial market. The core of the market is the German financial market, which is, together with the Austrian and that of Luxembourg, part of the eurozone. Luxembourg is known for its liberal financial regulations, which facilitate running financial services on an international scale. Switzerland is outside the eurozone, but it has the characteristics of an off-shore area. It is also a significant and excellent complement to the GSE financial market. Such a construction of GSE, based on both large amounts of capital and the differentiation of legal requirements, enables its stability and flexibility at the same time.

Financial products linked to protection of the natural environment have been offered on the GSE financial market for years (Deml, Baumgarten, and Bobikiewicz, 1994; Rotthaus, 2009, pp. 17-19; Dziawgo, 2010, pp. 81-130; Deml, and Blisse, 2016). There are, among others, shares and bonds of issuers considered as ecological, as well as accounts and bank deposits, shares of companies linked to protection of the natural environment and participation units in ecological investment funds. Therefore it may be concluded that the ecological financial market established on the GSE financial market is one of the leading ecological financial markets internationally.

Ecological investment funds on the GSE market are a significant part of the ecological financial market. Such funds were first established in the 1980s and 1990s. In the beginning of the 1990s, there were only a few of them, but later their number increased rapidly (Table 1 ).

The data presented in Table 1 proves that the pace of growth on the EIF market in terms of the number of funds and value of assets is high. What is more, just between 2010 and 2018, 98 new ecological investment funds were established (almost 44\% of all EIFs on the GSE market). This is yet another characteristic depicting the strong dynamics of the EFI market development in the GSE region.

However, in order to assess the state of the development of the EIF market, it is important to consider several facts that are listed below. 
Table 1. Development of the EIF market in the GSE region in 1996-2018 (as of $31^{\text {st }}$ December each year)

\begin{tabular}{|c|c|c|}
\hline Year & Number of funds & Value of assets (billion EUR) \\
\hline 1996 & 10 & 0.14 \\
\hline 2002 & 61 & 2.6 \\
\hline 2006 & 89 & 10.0 \\
\hline 2012 & 180 & 20.4 \\
\hline 2018 & 225 & 54.2 \\
\hline
\end{tabular}

Source: (Oeko-Invest, 1996, 2002, 2006, 2012, 2019).

Various types of EIF operate on the market in terms of, for instance, construction of the fund, investment policy and object of investments (Werner, 2009, pp. 121-128; Rotthaus, 2009, pp. 96-136; Deml, and Blisse, 2016, pp. 81-82). Clients considering ecological criteria have a wide choice of options. In Table 2, the classification of funds in terms of investments for the latest period of 2012-2018 is presented.

Table 2. Classification of EIF in terms of investment between 2012 and 2018 (as of $31^{\text {st }}$ December)

\begin{tabular}{|l|r|r|r|c|}
\hline \multirow{2}{*}{ Type of fund } & \multicolumn{2}{|c|}{ Number of funds } & \multicolumn{2}{c|}{ Value of assets (billion EUR) } \\
\cline { 2 - 5 } & 2012 & 2018 & 2012 & 2018 \\
\hline Stock & 105 & 125 & 12.1 & 33.7 \\
\hline Bond & 35 & 51 & 5.6 & 8.7 \\
\hline Mixed & 19 & 34 & 2.0 & 8.8 \\
\hline Money market fund & 2 & 2 & 0.1 & 0.2 \\
\hline Fund of funds & 11 & 7 & 0.2 & 0.2 \\
\hline Other & 8 & 6 & 0.4 & 2.6 \\
\hline Total & 180 & 225 & 20.4 & 54.2 \\
\hline
\end{tabular}

Source: (Oeko-Invest, 2012, 2019).

Based on the data presented in Table 2, between 2012 and 2018 the number of funds and their value of assets in primary categories, in terms of investment, rapidly increased. The dominance of stock funds is notable, followed by bonds and mixed funds. This structure of the ecological investment funds market has been in place for many years.

Analyzing the value of assets in investment funds, it may be concluded that there is notable differentiation. Among investment funds, several of them numbered significantly more assets, for instance:

- Pictet Water: 4.5 billion EUR,

- BNP Paribas Aqua Classic: 2.3 billion EUR,

- Raiffeisen Futura Swiss Stock: 1.1 billion EUR. 
There are also funds with a significantly lower value of assets, for instance:

- Legg Mason Clear Bridge US Eq. Sust. Leaders: 9 million EUR,

- Swisscanto EF Systematic Respons Global AA: 4 million EUR,

- Sustainable Alpha Fund: 1 million EUR.

This can be explained not only by the efficiency of investment and marketing policy, but also the longevity of the fund or the market position of owner of the fund.

It is important to note that the founder or tenderer of the funds are many key financial institutions, for instance: Allianz, BNP Paribas, Deka, Deutsche Bank, Erste, Fidelity, Raiffeisen, UBS, JSS, HSBC, Legg Mason, Black Rock, and SEB. Moreover, the engagement from financial institutions specialized in financing protection of the natural environment (Triodos, GLS Bank, UmweltBank) or private banking - wealth management (Pictet, J. Safra Sarasin,Vontobel) is also significant. Swiss canton banks (ZKB - Zuercher Kantonal Bank - funds from Swisscanto group) are present as well. Considering all the above-mentioned examples of institutions, it is worth noting that they represent not only German, Austrian, Swiss and Luxembourg capital, but also French, Swedish, Dutch, American and British capital. The presence of these many established financial institutions on the EIF market in the GSE region boosts the prestige and overall value of the market itself. Examples of engagement of selected financial institutions on the EIF market are presented in Table 3.

Table 3. Primary offering of selected financial institutions on the EIF market in the GSE region (31.12.2018)

\begin{tabular}{|l|c|c|c|}
\hline \multicolumn{1}{|c|}{ Name } & Stock fund & Bond fund & Other \\
\hline UBS & 4 & - & 1 \\
\hline Deutsche Bank & 1 & - & 1 \\
\hline Raiffeisen & 4 & 6 & 2 \\
\hline Allianz & 2 & 1 & - \\
\hline ZKB & 4 & - & 1 \\
\hline Vontobel & 3 & 1 & 3 \\
\hline Erste & 5 & 4 & - \\
\hline Triodos & 2 & 1 & - \\
\hline Pictet & 5 & - & 2 \\
\hline J. Safra Sarasin & 8 & 4 & - \\
\hline SEB & 1 & 1 & \\
\hline
\end{tabular}

Source: (Oeko-Invest, 2019).

Analyzing both the financial and ecological activity of the financial institutions, several leaders can be highlighted. One of them is the Swiss bank J. Safra Sarasin, which was one of the first that offered two investment funds with an ecological profile in the first half of 1990s. Several years later the range of such funds was being 
consistently developed. By the end of 2018 the bank had 14 ecological investment funds and their assets amounted to nearly 1.2 billion EUR. What is more, the bank specializes in services dedicated to high-net-worth individuals (HNWI). This proves that investors considering ecological criteria can be found in all groups of financial institutions' clients. Similarly, the activity of Raiffeisen, Erste, Pictet, Vontobel and ZKB in this field can be assessed positively. It should be noted however, that significantly more financial institutions could be more engaged on the EIF market in the GSE region.

\section{Critical aspects of ecological investment on the financial markets}

Considering the socially responsible investment (SRI) success in the GSE region, it is essential to note the critical aspects of such investments, also with regard to ecology. The concerns apply both to theoretical and practical aspects (Dziawgo, 2010, pp. 182-183).

From the synthetic point of view, they most often concern the following issues (Figure 2):

- the idea of corporate social responsibility (theory)

and

- the implementation of assumptions of this idea in business practice (practice).

Considering both the above-mentioned theoretical and practical scope, it is possible to list the following:

- true motives behind implementing CSR rules,

- scope of activities based on the idea of CSR,

- scale of these activities,

- ways of implementing them,

- efficiency of such activities.

Analyzing Figure 2, it can be concluded that it will not be possible to indicate the true motives behind implementing activities concerning protection of the natural development for financial institutions. Saving resources such as electric and heat energy, water, fuel, and paper has an obvious ecological meaning, but also translates into cost savings.

The scope of the pro-ecological activity of institutions could be also assessed critically. This activity is limited to several actions. The same may be said about their scale of ecological engagement, which may be limited to several units of the financial institution on either a national or international scale. The ways of implementing ecological activities may be debatable due to various solutions, accessible and implemented, both technological and financial ones.

The theoretical and practical aspects of corporate social responsibility (CSR), including the ecological factors, were presented above. Considering all the concerns, it is worth noting the intellectual aspect of this idea, since it reduces irresponsibility 


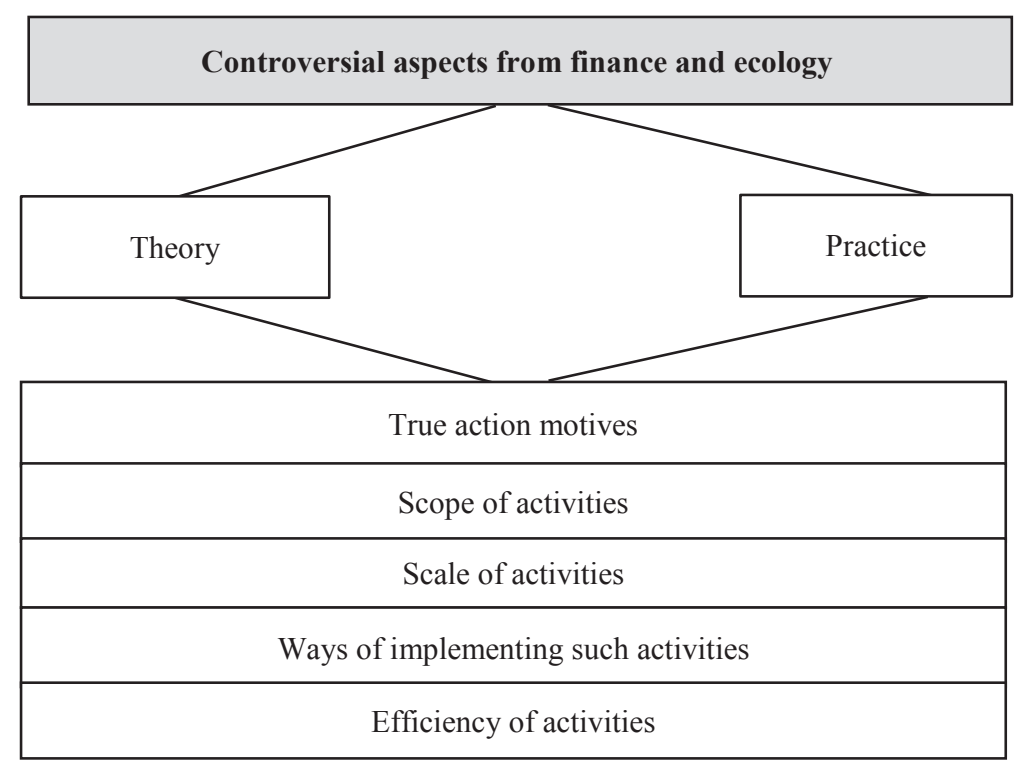

Fig. 2. Controversial aspects of ecological investments functioning on the financial markets Source: own analysis.

in business, both in legal and non-legal aspects, in according with the rule that not everything that is legally permitted, is socially accepted.

Obviously, such an assessment of the efficiency of the undertaken actions in terms of saving natural resources and proposing investment solutions to clients may be subject to the debate.

However, considering the investments on the financial market in compliance to ecological criteria, it can be concluded that the offered range could be broader due to their potential. Their engagement may be often regarded as minimal, provided only for reassuring public opinion and selected stakeholders.

\section{Conclusion}

Ecological investment funds' market in German-speaking Europe is one of the most crucial regarding ecological investments on the international financial market. The presented data proves that the development of this market is rapid.

It is evidenced by the increase in the number of ecological investment funds, and by the growth in the value of their financial assets. In the article, several other characteristics of the EIF market's development were highlighted as well, such as the diversified range of ecological investment funds and the presence of well-established financial institutions, even outside of the GSE. 
The primary conclusion from the conducted research is that further development of the presented market is to be expected. However, numerous financial institutions could be more engaged in the ecological investment funds market.

There is an opportunity for the dynamic development of the EIF market in German-speaking Europe, due to its close proximity and potential, which could positively impact on establishing a part of the Polish financial market oriented onto financial investments in respect of the CSR, including ecological criteria.

\section{Bibliography}

Deml, M., Baumgarten, J., and Bobikiewicz, L. (1994). Gruenes Geld. Wien: Service Fachverlag.

Deml, M., and Blisse, H. (2016). Gruenes Geld 2020, Wien: medianet Verlag.

Dziawgo, D. (2012). Relacje inwestorskie. Warszawa: Wydawnictwo Naukowe PWN.

Dziawgo, L., (2010), Zielony rynek finansowy. Warszawa: PWE.

Dziawgo, L., (2014), Greening financial market. Copernican Journal of Finance \& Accounting, (2), 9-23.

Eurosif (2019). European SRI Study 2018, http://www.eurosif.org/wp-content/uploads/2018/11/European-SRI-2018-Study-LR.pdf.

Gabriel, K., 2007, Nachhaltigkeit am Finanzmarkt. Muenchen: oekom.

Krupa, D., 2012, Fundusze inwestycyjne odpowiedzialne społecznie. Annales, Oeconomia, Sectio H, UMCS, vol. XLVI, (1).

Oeko-Invest (1996). (116).

Oeko-Invest (2002). (265).

Oeko-Invest (2006). (362).

Oeko-Invest (2012). (516).

Oeko-Invest (2019). (664).

Rotthaus, S. (2009). Erfolgreich investieren in gruene Geldanlagen. Frankfurt/New York: Campus Verlag.

Staub-Bisang, M. (2012). Sustainable Investing for Institutional Investors. Singapore: John Wiley \& Sons.

Ulshoefer, G., and Bonnet, G. (2009). Corporate Social Responsibility auf dem Finanzmarkt, Wiesbaden: VS Verlag fuer Sozialwissenschaften.

Upgang, M. (2009). Gewinn mit Sinn. Muenchen: oekom.

Werner, T. (2009). Oekologische Investments. Wiesbaden: Gabler. 